\title{
Investigating the Export Competitiveness of Indonesian Automobile in the Middle-East Countries
}

\author{
Abi Revyansah Perwira \\ Badan Pusat Statistik Kabupaten Tabalong \\ JL. Jaksa Agung Soeprapto no. 82, Tanjung, Tabalong 71513, Indonesia \\ E-mail: abi.revyansah@bps.go.id
}

\begin{abstract}
Abstrak
Karena mobil merupakan salah satu komoditas Indonesia bernilai tambah dengan potensi ekspor tertinggi, paper ini mengkaji daya saing mobil Indonesia di negara-negara Timur Tengah terpilih dengan menggunakan indeks RSCA, EPD, dan $X$-Model. Indeks RSCA mengungkapkan bahwa mobil Indonesia memiliki keunggulan komparatif di Bahrain, Kuwait, Lebanon, Oman, Qatar, SA, dan UEA. Matriks EPD menunjukkan bahwa Indonesia memiliki posisi Rising Star di Bahrain, Kuwait, Lebanon, Oman, dan SA. Hasil X-Model menyimpulkan bahwa Bahrain, Kuwait, Lebanon, Oman, dan SA optimistis untuk ekspansi ekspor mobil Indonesia. Indonesia harus fokus pada pengembangan ekspor SUV karena model ini memiliki permintaan tertinggi di negara-negara Timur Tengah. Dengan melonggarkan pajak atas penjualan dalam negeri model ini bisa meningkatkan jumlah produksi yang menciptakan harga yang lebih kompetitif untuk ekspor.
\end{abstract}

Kata kunci: EPD, Daya Saing Ekspor, Mobil Indonesia, RSCA

\begin{abstract}
Since the automobile is one of Indonesia's value-added commodities with the highest export potency, this paper investigates the competitiveness of Indonesian automobile in the selected Middle-east countries by employing the RSCA index, the EPD, and the X-Model. The RSCA indices reveal that the Indonesian automobile has a comparative advantage in Bahrain, Kuwait, Lebanon, Oman, Qatar, SA, and the UAE. The EPD matrix displays that Indonesia has Rising Star positions in Bahrain, Kuwait, Lebanon, Oman, and SA. The X-Model result concludes that Bahrain, Kuwait, Lebanon, Oman, and SA are optimistic for Indonesian automobile export expansion. Indonesia should focus on SUV export development since this model has the highest demand in the Middle-east countries. By relaxing tax on the domestic sales of the model could increase the production number creating more competitive price for export.
\end{abstract}

Keywords: EPD, Export Competitiveness, Indonesian Automobile, RSCA

\section{Introduction}

Export is an essential instrument for a country that can boost the Gross Domestic Product (GDP) through foreign exchange revenue. Also, the export market usually defines some new quality standards of export commodities which encourage exporter countries to develop the competitiveness of their export commodities.

Unfortunately, as a country with the largest population and natural resources in the ASEAN, Indonesia's export contribution to GDP is still low where Indonesia is the $8^{\text {th }}$ rank among the ASEAN countries in 2019 (TABLE I). Moreover, Indonesia export is still dominated by raw and intermediate commodities from agriculture and mining sectors such as oil, gas, coal, Crude Palm Oil (CPO), and rubber. Hence, Indonesia requires to improve its manufacturing industries which focus on producing value-added commodities.

TABLE I

ASEAN COUNTRIES' EXPORT CONTRIBUTION TO GDP (\%)

\begin{tabular}{|c|c|c|c|c|}
\hline Country & 2016 & 2017 & 2018 & 2019 \\
\hline Brunei Darussalam & 49.58 & 49.57 & 51.93 & 57.95 \\
\hline Cambodia & 61.28 & 60.68 & 61.60 & 61.09 \\
\hline Indonesia & 19.09 & 20.18 & 20.97 & 18.41 \\
\hline Lao PDR & 33.21 & N/A & N/A & N/A \\
\hline Malaysia & 66.78 & 70.01 & 68.57 & 65.22 \\
\hline Myanmar & 25.94 & 28.36 & 30.39 & N/A \\
\hline The Philippines & 26.67 & 29.55 & 30.21 & 28.34 \\
\hline Singapore & 165.09 & 170.71 & 177.68 & 173.52 \\
\hline
\end{tabular}

111 | Jurnal Akuntansi, Ekonomi dan Manajemen Bisnis | Vol. 9 No.2, December 2021, 111-121 | E-ISSN: 2548-9836 


\begin{tabular}{|c|c|c|c|c|}
\hline Thailand & 67.06 & 66.68 & 64.87 & 59.77 \\
\hline Vietnam & 93.62 & 101.59 & 105.83 & 106.80 \\
\hline
\end{tabular}

SOURCE: WORLD BANK (2021)

According to the Ministry of Trade Republic of Indonesia, Indonesia's most potential value-added commodity is automobile. This fact is supported by Gabungan Industri Kendaraan Bermotor Indonesia (Gaikindo) where the Indonesian automobile industry experiences prosperous growth for the last 15 years in domestic sales and export performance (Figure 1).

Nonetheless, Figure 1 also reveals the wide gap between domestic sales and export. Large domestic demand, importer countries' protective regulations, low capital investment, lack of product differentiation, and/or poor global market connections are pointed out as some possible reasons for the gap (Abedini \& Péridy, 2009).

The Ministry of Industry Republic of Indonesia created "Making Indonesia 4.0" program in 2018 to strengthen automobile export. One of this program long-term primary targets is Indonesia must be the automobile export leader in the ASEAN region. Therefore, to support the "Making Indonesia 4.0" program, Indonesia requires a strategy to improve its automobile export performance.

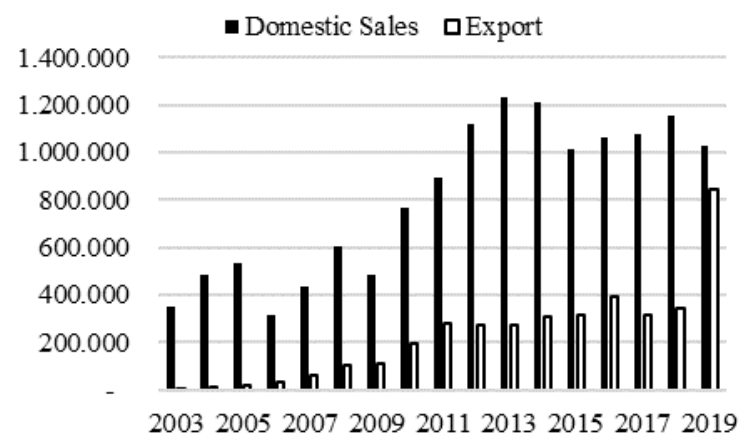

Figure 1: Indonesia Automobile Sales and Export (units) (Gaikindo, 2021)

To arrange an appropriate strategy on automobile export, the export competitiveness of Indonesian automobile must be identified. Thus, an investigation on the export competitiveness of Indonesian automobile is relevant to be examined.

Since previous empirical studies of Indonesia export competitiveness mostly analyze agricultural commodities (Ermawati \& Saptia, 2013; Hasibuan et al., 2012; Kaunang, 2013; Nihayah, 2012; Sarwono \& Pratama, 2014; Zuhdi \& Suharno, 2015), the export competitiveness of Indonesian automobile might not be investigated yet. Only the Organization for Economic Co-operation and Development (OECD) observed the export competitiveness of Indonesian automobile together with four other sectors. However, the OECD did not analyze the export competitiveness specifically and deeply.

To clarify where Indonesia should expand its automobile export, the trade partners identification is essential in export competitiveness studies. This paper proposes the Middle-east region as one of Indonesia's export target. Despite some Middle-east countries are suffering from civil-war such as Syria and Yemen, most of the Middle-east countries are prospective as export destination countries since they have high GDP per capita and a growing population.

Moreover, previous studies about Indonesia export competitiveness did not discuss specifically the Middle-east countries. Mostly discuss in the global export market (Alexander \& Nadapdap, 2019; Asrol \& Heriyanto, 2017; Ermawati \& Saptia, 2013; Hagi et al., 2012; Hasibuan et al., 2012; Mashari et al., 2019; Nauly et al., 2014; Nihayah, 2012; Pradipta, 2014; Purnamasari et al., 2014; Syahputra et al., 2014; Tupamahu, 2015) and/or in the specific countries (Ashari et al., 2016; Kusuma \& Firdaus, 2015; Nurhayati et al., 2018; Pradipta, 2014; Sari et al., 2014; Siburian, 2012; Virginia \& Novianti, 2020) which do not imply strategy how to improve export performance in the specific region.

Regarding the background, this paper attempts to investigate the export competitiveness of Indonesian automobile in the Middle-east countries. This paper is conducted as follows. First, this paper provides earlier studies about the Revealed Comparative Advantage (RCA), the Revealed Symmetric Comparative Advantage (RSCA), and the Export Product Dynamics (EPD in the Literature Review section. Second, the dataset and the investigation tools are explained in the Research Method section. Third, the Result and Discussion section describe the finding and the analysis result. And the last, summary and policy recommendations are provided in the Conclusion section.

\section{Literature Review}

The RCA was introduced firstly by Balassa in 1965 and became popular as a tool to measure export competitiveness. The RCA calculates a country's commodity export relative to the commodity total import of a country, region, or even the world. A country's commodity tends to have high demand in the export market if the commodity has more comparative advantage than that from other countries. Many past studies employ the RCA and combine it with other measurement methods.

Suntharalingam et al. (2011) utilize the RCA and the Comparative Export Performance (CEP). Based on the RCA indices, Malaysian watermelon defeats Thailand, Indonesia, the Philippines, Singapore, China, and India in the world market. While the CEP reveals that 
Malaysia has the strongest competitiveness in exporting watermelon and papaya to Singapore and Hong Kong.

Bano \& Scrimgeour (2012) applies the RCA and gravity models to investigate the export performance of New Zealand's Kiwifruit. The RCA indices show that New Zealand's Kiwifruit has strong competitiveness in the world market and the gravity models find that importers' GDP, location, and trade agreement have a significant influence on Kiwifruit export performance.

Hasibuan et al. (2012) employ three methods to measure the export performance of cocoa bean and its intermediate commodities, the RCA, the EPD, and the Constant Market Share Analysis (CMSA). The RCA indices shows that the export competitiveness of Indonesian cocoa commodities is far below Ivory Coast and Ghana. Nevertheless, Indonesian cocoa commodities still have a comparative advantage. The EPD informs that almost all cocoa commodities have a competitive advantage while the CMSA shows that the intermediate commodities have a higher competitive advantage than the cocoa bean.

The RCA and the CMSA are also applied by Ermawati $\&$ Saptia (2013) to observe the export competitiveness of Indonesian CPO and Palm Kernel Oil (PKO). Based on the RCA indices, the export performance of Indonesian CPO and PKO are lower than those of Malaysia and Thailand. The CMSA analysis finds that Indonesian CPO and PKO tend to decrease in the global market.

Herciu (2013) employs the RCA and Porter's Diamond Model (PDM) on the international competitiveness of Romanian export commodities. The RCA indices reveal that Romania has more competitive disadvantage than a competitive advantage. The PDM suggests that Romania should reduce its production costs, improve the quality of its commodities, expand its export market, and maintain its exchange rate and current account deficit.

The RCA and the PDM are also utilized by Kaunang (2013) in examining the export competitiveness of Indonesian coconut oil. Based on the RCA indices, Indonesian coconut oil has decreased since 2010. The PDM describes that the Government of Indonesia (GoI) should improve the infrastructure in North Sulawesi, subsidize the fertilizer for coconut plant, and develop the technology of the coconut oil industry.

Mushanyuri \& Mzumara (2013) only employs the RCA to investigate the export commodities of Mauritius in the Southern African Development Community (SADC), the Common Market for Eastern and Southern Africa (COMESA), and the global markets. The RCA indices reveal that Mauritius has export competitiveness in 529 commodities codes where live primates are the most competitive.

Sarwono \& Pratama (2014) uses the RCA to observes the export competitiveness of Indonesian soybean and time-series regression to investigate the determinant factors of the RCA index. Indonesian soybean has weak export competitiveness with the RCA indices lower than one. Based on the time-series regression analysis, soybean production and export are the significant determinant factors of the Indonesian soybean RCA index.

Zuhdi \& Suharno (2015) analyzes the export competitiveness of Indonesian and Vietnamese coffee in the ASEAN 5 market by applying the RCA and the EPD. The RCA indices indicate that Vietnam has better export competitiveness than Indonesia. Based on the EPD, the export performance of both countries is growing fast and very dynamic because of the increase of coffee demand in the ASEAN 5 market.

Nevertheless, since the RCA index suffers from its asymmetric index. For this reason, several studies suggest the RSCA and compare between the RCA and the RSCA such as Laursen (2015), Ndubuto et al. (2010), Nihayah (2012), Rossato et al. (2018), and Startienè \& Remeikienè (2014). Laursen (2015) proves empirically that the RSCA is the best export competitiveness index among other indices such as the Michaely, the Contribution to Trade Balance, Chi-Square, and Bowen's Net Trade Indices. Moreover, Laursen (2015) also shows how to use RCA and RSCA indices to measure the export competitiveness stability and trend.

From the explanation above, this paper applies the RSCA since it is the most reliable in measuring export competitiveness. Also, since there is no study using the RSCA index in calculating export competitiveness stability and trend yet, this paper utilizes Laursen's (2015) method to analyze the export competitiveness stability and trend of Indonesian automobile export in the Middle-east countries.

\section{Research Methods}

This paper employs the secondary annual data acquired from UN Comtrade and International Trade Centre (ITC) period 2005-2019. At the outset, this paper explains briefly descriptive statistic about automobile import in the Middle-east region. The export commodity is all automotive commodities which are included in HS code 8703 (Motor cars and other motor vehicles; principally designed for the transport of persons). Next, this paper analyzes the competitiveness level, trend, and stability of Indonesian automobile export in the Middle-east countries.

This paper splits the analysis into three parts: first, this paper investigates the competitiveness level of Indonesian automobile export in selected trade partners 
individually during the period by applying the RSCA method. Second, from the RSCA indices, this paper provides the trend and stability of the export competitiveness.

Balassa (1965) proposes the RCA index as follow:

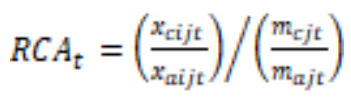

where:

$R C A_{t}$ : the RCA index in year $t$

$x_{\text {eijt }}:$ the export value of $c$ commodity from country $i$ to country $j$ in year $t$

$x_{\text {aijt }}$ : the total export value from country $i$ to country $\tilde{j}$ in year $t$

$m_{\text {ejt }} \quad$ : country $j$ 's $c$ commodity total import value in year $t$

$m_{a j t}$ : country $j$ 's total import value in year $t$

If $R C A_{\mathrm{t}}>1$ then the exporter country has a comparative advantage of $c$ commodity, otherwise it has a comparative disadvantage.

Since the RCA index suffers from asymmetry problem, Laursen (2015) develops the RSCA with the following formula:

$$
R S C A_{\mathrm{t}}=\left(R C A_{\mathrm{t}}-1\right) /\left(R C A_{\mathrm{t}}+1\right)
$$

If $R S C A_{t}>0$ then the exporter country has a comparative advantage of $c$ commodity, otherwise it has a comparative disadvantage.

The RSCA index from equation (2) can be used to calculate the competitiveness stability by applying the following regression equation:

$$
R S C A_{\mathrm{t}}=\alpha+\beta\left(R S C A_{\mathrm{t}-1}\right)+\varepsilon_{\mathrm{t}}
$$

$\alpha$ and $\beta$ are the regression coefficients from equation (3) solution. $\beta$ represents the competitiveness stability of $c$ commodity. If $\beta$ far from 1 then the competitiveness highly fluctuates. $\beta / R$ represents the competitiveness trend of $c$ commodity where $R$ is the correlation coefficients of equation (3). If $\beta / R>1$ then the competitiveness has an increasing trend, otherwise it has a decreasing trend.

According to Wardani \& Mulatsih (2017), the EPD is used to identify the market position dynamics of a commodity in trade partner countries. Esterhuizen (2006) describes that the EPD matrix utilizes market attractiveness as the $\mathrm{X}$-axis and business strength as the Y-axis. Also, the EPD matrix is divided into 4 positions: "Rising Star", "Falling Star", "Lost Opportunity", and "Retreat" (Figure 2). "Rising Star" is the most favorable position where the export commodity could grow rapidly. "Falling star" is an unfavorable position where the export commodity falls when the export market share rises. "Lost Opportunity" is the least favorable position where the export commodity is competitive but the market share of the exporter country decreases. "Retreat" might be an unfavorable position but it might be an input for the exporter country to switch and support other more competitive commodities.

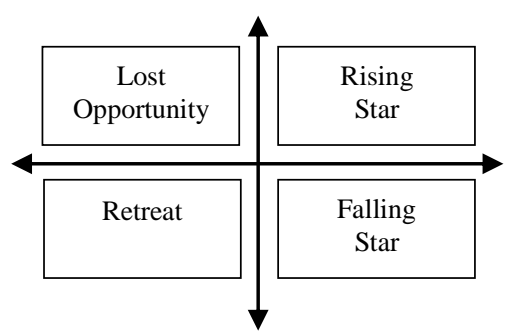

Figure 2: The EPD Matrix

The X-axis is the position of country $i$ 's $c$ commodity export share in importer country $j$ which is determined by the following formula:

$$
\frac{\sum_{t=1}^{t}\left(\frac{x_{c i j}}{m_{c j}}\right)_{t} \times 100 \%-\Sigma_{t=1}^{t}\left(\frac{x_{c i j}}{m_{c j}}\right)_{t-1} \times 100 \%}{T}(4)
$$

The Y-axis is the position of country $i$ 's total export share in importer country $j$ which is determined by the following formula:

$$
\frac{\sum_{t=1}^{t}\left(\frac{x_{a i j}}{m_{a j}}\right)_{t} \times 100 \%-\sum_{t=1}^{t}\left(\frac{x_{a i j}}{m_{a j}}\right)_{t-1} \times 100 \%}{T}(5)
$$

where $T$ is total observation years.

The RSCA indices and the EPD can be combined to cluster export market expansion and called X-Model Potential Export Products (Nurhayati et al., 2018). The cluster can be determined as follows:

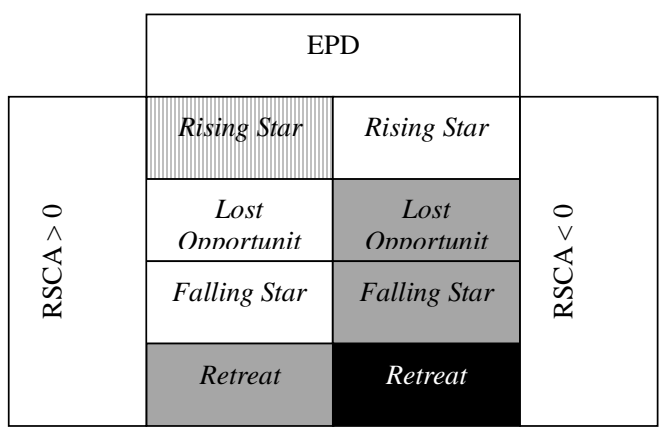

Figure 3: X-Model Potential Export Products Analysis 114 | Jurnal Akuntansi, Ekonomi dan Manajemen Bisnis | Vol. 9 No.2, December 2021, 111-121 | E-ISSN: 2548-9836 
The description of patterns:

\begin{tabular}{|c||c|}
\hline $\begin{array}{c}\text { Optimistic Export } \\
\text { Expansion }\end{array}$ & $\begin{array}{c}\text { Potential Export } \\
\text { Expansion }\end{array}$ \\
\hline \hline $\begin{array}{c}\text { Less Potential Export } \\
\text { Expansion }\end{array}$ & $\begin{array}{c}\text { Non-Potential Export } \\
\text { Expansion }\end{array}$ \\
\hline
\end{tabular}

\section{Result and Discussion}

Indonesian automobile demand is prospective in many countries. 80 countries are regular importers of Indonesian automobile. Thanks to Trade Agreements such as Preferential Trade Agreement (PTA), Free Trade Agreement (FTA), or Comprehensive Economic Partnership Agreement (CEPA), Indonesian automobile export have increased. Especially the Middle-east region where the export potency of Indonesian automobile still could grow.

The Middle-east countries are well-known as automobile lovers, low-price fuel, and lack of public transportation which make them the potential market for automobiles. The Middle-east countries choose Indonesian automobile because there is no strict regulation in emission standard and the price of Indonesian automobile is also quite competitive. About $34 \%$ of Indonesian automobile are exported to the Middle-east countries. The Middle-east countries which also automobile producers are Iran and Egypt. They also pursue exporting automobile which could be the primary competitors for Indonesia in the Middle-east market.

Although there are conflicts and wars in the Middle-east region such as in Palestine, Syria, and Yemen, they do not influence the automobile export flow to the region significantly. The export market for Indonesian automobile in the conflicted countries is relatively small.

From APPENDIX I, Iran has the highest number of automobile sales while Jordan is the lowest. APPENDIX I also exposes a declining trend of automobile sales in the Middle-east countries since 2016. The automobile demand was drop because of the falling international oil price. Since the Middle-east region is the largest oil supplier in the world, the oil price crisis affected the economy of the region seriously. Indonesian automobile also experienced decreasing export performance during the crisis period.

TABLE II

THE EXPORT COMPETITIVENESS STABILITY \& TREND

\begin{tabular}{|c|c|c|}
\hline Country & Stability $(\beta)$ & Trend $(\beta / R)$ \\
\hline Bahrain & 0.5090 & 0.7589 \\
\hline Egypt & 0.6100 & 0.9917 \\
\hline
\end{tabular}

\begin{tabular}{|c|c|c|}
\hline Jordan & 0.7483 & 1.2051 \\
\hline Kuwait & 0.7674 & 0.8458 \\
\hline Lebanon & 0.1342 & 0.8264 \\
\hline Oman & 0.2493 & 0.7254 \\
\hline Qatar & 0.6877 & 1.0285 \\
\hline Saudi Arabia & 0.4769 & 0.7528 \\
\hline The UAE & 0.1804 & 0.7220 \\
\hline
\end{tabular}

SOURCE: AUTHOR's CALCULATION

Multi-purpose Vehicle (MPV) model is the main products of Indonesian automobile manufacturers, especially the Toyota brand. Famous variants such as Avanza, Innova, Fortuner, Grand Max, Hilux and Terios dominate not only Indonesia's domestic sales but also Indonesia's export. Most of these variants are also exported to the Middle-east countries. From 15 Middle-east countries, only 9 countries who are Indonesia's partners in automobile trade consistently since 2006: Bahrain, Egypt, Jordan, Kuwait, Lebanon, Oman, Qatar, Saudi Arabia (SA), and the United Arab Emirates (UAE). Based on APPENDIX II, the biggest Indonesian automobile importer is SA while the smallest is Jordan.

Although the export value of Indonesian automobile has an escalating trend before the falling global oil price, it does not mean that the export competitiveness also increases. APPENDIX III reveals that the Indonesian automobile has a comparative advantage in Bahrain, Kuwait, Lebanon, Oman, Qatar, SA, and the UAE with positive average RSCA indices. While Egypt and Jordan show a comparative disadvantage. Based on TABLE II, the export competitiveness stability has a mid-high fluctuation since $\beta$ is far from 1 , particularly in Lebanon and the $\mathrm{UAE}$ where $\beta$ is almost zero. Also, TABLE II shows that the export competitiveness trend increases only in Jordan and Qatar while the others show a decreasing trend.

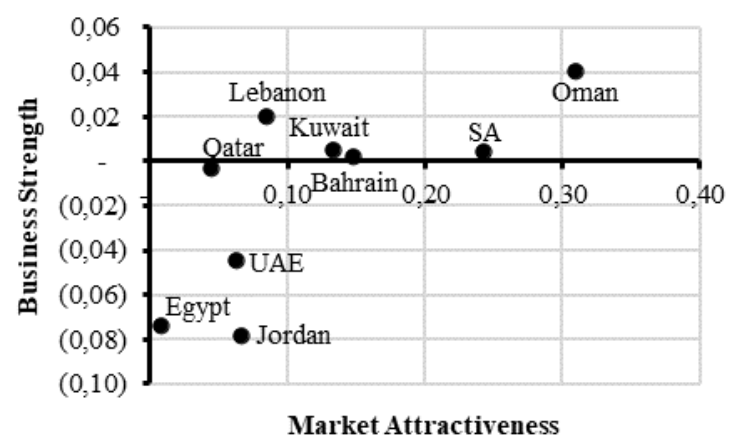

Figure 4: The EPD Matrix of Indonesian Automobile Export in the Selected Middle-East Countries

Figure 4 displays the market positions of Indonesian automobile in the selected Middle-east countries. 
Indonesia has Rising Star positions in Bahrain, Kuwait, Lebanon, Oman, and SA. Indonesia's automobile market share rises inline with the increase of its total export share in those countries, while the others show Falling Star positions although the Indonesian automobile shows an improvement in export performance.

TABLE III

The X-Model ANALysis Result of Indonesian Automobile EXPORT IN THE SELECTED MIDDLE-EAST COUNTRIES

\begin{tabular}{|c|c|c|c|}
\hline Country & Average RSCA & EPD & X-Model \\
\hline Bahrain & 0.5217 & Rising Star & Optimistic \\
\hline Egypt & -0.3870 & Falling Star & Less Potential \\
\hline Jordan & -0.5423 & Falling Star & Less Potential \\
\hline Kuwait & 0.2648 & Rising Star & Optimistic \\
\hline Lebanon & 0.4123 & Rising Star & Optimistic \\
\hline Oman & 0.3823 & Rising Star & Optimistic \\
\hline Qatar & 0.3746 & Falling Star & Potential \\
\hline SA & 0.4542 & Rising Star & Optimistic \\
\hline The UAE & 0.1083 & Falling Star & Potential \\
\hline
\end{tabular}

SOURCE: AUTHOR's CALCULATION

Based on the TABLE III, Indonesia has optimistic export expansions in Bahrain, Kuwait, Lebanon, Oman, and SA where Indonesia could increase automobile export number and expand the model variants. Although Qatar and the UAE have Falling Star positions, they still have potential for export expansion. Meanwhile, Indonesia could surrender in Egypt and Jordan since they are less potential.

From the X-Model, Indonesia should treat countries with optimistic and potential export expansion result as potential trade partners and develop a mutual relationship. However, Indonesia require specific bilateral approaches and export strategies to gain more market share in the less potential Middle-East countries. The Middle-east countries are still dominated by giant automobile producer countries such as Japan, Germany, the USA, and the Republic of Korea. These are proofs that geographical distance is not relevant anymore but brand image and marketing strategy play the role more. The main issue in the Indonesian automobile industry is model differentiation. Indonesia automobile production is mostly the MPV model because this model is the most favorite model for Indonesian customers. On the other hand, the Sport Utility Vehicle (SUV) has the highest sales in the Middle-east countries.

Since the SUV taxed higher than the MPV in Indonesia's domestic market, the MPV became the most demanded model. For this reason, the local automobile manufacturers also produce the MPV for the export market to achieve lower average production costs. As a result, the price of MPV is more competitive in both markets. According to Director General of Metal, Machinery, Transportation Equipment, and Electronics Industry (ILMATE), Indonesia requires to enact tax relaxation on the SUV, so the domestic demand on the SUV could rise and simultaneously stimulate the production for the export market (Gaikindo, 2019). The primary strength of the Indonesian automobile industry is the domestic market. Therefore, no local manufacturers would produce models which are not attractive to the domestic market. The automobile producers are afraid of profit loss if they rely on the export market only.

\section{Conclusions}

The export competitiveness of Indonesian automobile still has the potency to grow in the Middle-east countries although some countries are suffering from wars. $34 \%$ of Indonesian automobile export in the world are absorbed by the Middle-east countries.

The RSCA indices from the selected Middle-east countries reveal that the Indonesian automobile has a comparative advantage in Bahrain, Kuwait, Lebanon, Oman, Qatar, SA, and the UAE while Egypt and Jordan show a comparative disadvantage. The export competitiveness stability has medium to extreme fluctuations, particularly in Lebanon and the UAE. The export competitiveness shows an increasing trend only in Jordan and Qatar while the other countries show a decreasing trend.

The EPD matrix displays that Indonesia has Rising Star positions in Bahrain, Kuwait, Lebanon, Oman, and SA. While Falling Star positions are shown in Egypt, Jordan, Qatar, and the UAE.

Meanwhile, the X-Model result concludes that Bahrain, Kuwait, Lebanon, Oman, and SA are optimistic for Indonesian automobile export expansion. Qatar and the UAE are potential for the expansion. Therefore, Indonesia should manage special bilateral approaches with those optimistic and potential countries.

Indonesia should focus on SUV export development since this model has the highest demand in the Middle-east countries. The appropriate strategy for Indonesian automobile export expansion is increasing the SUV production number by relaxing the tax on the SUV in the domestic market.

\section{References}

A. Abedini, J., \& Péridy, N. (2009). The Emergence of Iran in the World Car Industry: An Estimation of its Export Potential. World Economy,32(5),790-818.https://doi.org/10.11 11/j.1467-9701.2008.01153.x 
B. Alexander, I., \& Nadapdap, H. J. (2019). Analisis Daya Saing Ekspor Biji Kopi Indonesia Di Pasar Global Tahun 2002-2017. Jurnal Sosial Ekonomi Pertanian, 12(2), 1. https://doi.org/10.19184/jsep.v12i2.11271

C. Ashari, U., Sahara, S., \& Hartoyo, S. (2016). Daya Saing Udang Segar Dan Udang Beku Indonesia Di Negara Tujuan Ekspor Utama. Jurnal Manajemen Dan Agribisnis, 13(1), 1-13. https://doi.org/10.17358/jma.13.1.1

D. Asrol, A., \& Heriyanto, H. (2017). Daya Saing Ekspor Pala Indonesia di Pasar Internasional. Jurnal Dinamika Pertanian, 33(2), 179-188. https://doi.org/10.25299/dp.2017.vol33(2).38 31

E. Balassa, B. (1965). Trade Liberalisation and "Revealed" Comparative Advantage. The Manchester School of Economic and Social Studies, 32, 99-123.

F. Bano, S., \& Scrimgeour, F. (2012). The Export Growth and Revealed Comparative Advantage of the New Zealand Kiwifruit Industry. International Business Research, 5(2), 73-82. https://doi.org/10.5539/ibr.v5n2p73

G. Ermawati, T., \& Saptia, Y. (2013). Kinerja Ekspor Minyak Kelapa Sawit Indonesia. Buletin Ilmiah Litbang Perdagangan, 7(2), 129-148.

H. Esterhuizen, D. (2006). Measuring and Analyzing Competitiveness in the Agribusiness Sector: Methodological and Analytical Framework. University of Pretoria, 107(4), 823-824. https://doi.org/10.1086/689555

I. Gaikindo. (2019). Pemerintah Janjikan Pajak Sedan Turun. Artikel Economy \& Industry. https://www.gaikindo.or.id/pemerintah-janjik an-pajak-sedan-turun/

J. Gaikindo. (2021). Indonesian Automobile Industry Data. Data. https://www.gaikindo.or.id/en/indonesian-aut omobile-industry-data/

K. Hagi, Hadi, S., \& Tety, E. (2012). Analisis Daya Saing Ekspor Minyak Sawit Indonesia dan Malaysia di Pasar Internasional. Repository Universitas Riau.

L. Hasibuan, A. M., Nurmalina, R., \& Wahyudi, A. (2012). Analisis Kinerja dan Daya Saing Perdagangan Biji Kakao dan Produk Kakao Olahan Indonesia di Pasar Internasional. Buletin Riset Tanaman Rempah Dan Aneka Tanaman Industri, 3(1), 57-70. https://doi.org/10.21082/jtidp.v3n1.2012.p57
M. Herciu, M. (2013). Measuring International Competitiveness of Romania by Using Porter's Diamond and Revealed Comparative Advantage. Procedia Economics and Finance, 6(2013), 273-279. https://doi.org/10.1016/S2212-5671(13)0014 $0-8$

N. International Trade Centre. (2021). Trade Statistics for International Business Development. Trade Map. https://www.trademap.org

O. Kaunang, W. R. (2013). Daya Saing Ekspor Komoditi Minyak Kelapa Sulawesi Utara. Jurnal Riset Ekonomi, Manajemen, Bisnis Dan Akuntansi, 1(4), 1304-1316.

P. Kusuma, R. L., \& Firdaus, M. (2015). Daya Saing dan Faktor yang Memengaruhi Volume Ekspor Sayuran Indonesia Terhadap Negara Tujuan Utama. Jurnal Manajemen Dan Agribisnis, 12(3), 226-236. https://doi.org/10.17358/jma.12.3.226

Q. Laursen, K. (2015). Revealed Comparative Advantage and the Alternatives as Measures of International Specialization. Eurasian Business Review, 5(1), 99-115. https://doi.org/10.1007/s40821-015-0017-1

R. Mashari, S., Nurmalina, R., \& Suharno. (2019). Dinamika Daya Saing Ekspor Udang Beku dan Olahan Indonesia di Pasar Internasional. Jurnal Agribisnis Indonesia, 7(1), 37-52.

S. Mushanyuri, B. E., \& Mzumara, M. M. (2013). An Assessment of Comparative Advantage of Mauritius. European Journal of Sustainable Development, 2(3), 35-42. https://doi.org/10.14207/ejsd.2013.v2n3p35

T. Nauly, D., Daris, E., \& Nuhung, I. A. (2014). Daya Saing Ekspor Kakao Olahan Indonesia. Agribusiness Journal, 8(1), 15-28. https://doi.org/10.15408/aj.v8i1.5126

U. Ndubuto, I., Agwu, N., Nwaru, J., \& Imonikhe, G. (2010). Competitiveness and Determinants of Cocoa Export from Nigeria. Report and Opinion, 2(7), 51-54.

V. Nihayah, D. M. (2012). Kinerja Daya Saing Komoditas Sektor Agroindustri Indonesia. Jurnal Bisnis Dan Ekonomi, 19(1), 37-48.

W. Nurhayati, E., Hartoyo, S., \& Mulatsih, S. (2018). Analisis Pengembangan Ekspor Cengkeh Indonesia. Jurnal Ekonomi Dan Kebijakan Pembangunan, 7(1), 21-42.

X. OECD. (2012). OECD Reviews of Regulatory Reform: Indonesia Market Openess (Issue

117 | Jurnal Akuntansi, Ekonomi dan Manajemen Bisnis | Vol. 9 No.2, December 2021, 111-121 | E-ISSN: 2548-9836 
September

2012).

OECD.

http://www.oecd-ilibrary.org/content/book/97 89264042940 -en\%5Cn

Y. OICA. (2021). Sales Statistics. http://www.oica.net/category/sales-statistics/

Z. Pradipta, A. (2014). Posisi Daya Saing dan Faktor-Faktor Yang Memengaruhi Ekspor Buah-Buahan Indonesia. Jurnal Manajemen \& Agribisnis, 11(2), 129-143. https://doi.org/10.17358/jma.11.2.129-143

AA. Purnamasari, M., Hanani, N., \& Huang, W.-C. (2014). Analisis Daya Saing Ekspor Kopi Indonesia di Pasar Dunia. Agricultural Socio-Economic Journal, 14(1), 58-66. https://agrise.ub.ac.id/index.php/agrise/article /view/117/143

BB. Rossato, F. G. F. S., Susaeta, A., Adams, D. C., Hidalgo, I. G., Araujo, T. D. De, \& Queiroz, A. De. (2018). Comparison of Revealed Comparative Advantage Indexes with Application to Trade Tendencies of Cellulose Production from Planted Forests in Brazil, Canada, China, Sweden, Finland and the United States. Forest Policy and Economics, 97(September),

$59-66$. https://doi.org/10.1016/j.forpol.2018.09.007

CC. Sari, A. R., Hakim, D. B., \& Anggraeni, L. (2014) Analisis Pengaruh Non-Tariff Measures Ekspor Komoditi Crude Palm Oil (CPO) Indonesia Ke Negara Tujuan Ekspor Utama. Jurnal Ekonomi Dan Kebijakan Pembangunan, 3(2), 111-135. https://doi.org/10.29244/jekp.3.2.111-135

DD. Sarwono, \& Pratama, W. (2014). Analisis Daya Saing Kedelai Indonesia. Jurnal Ekonomi Dan Kebijakan, 7(2), 134-140. https://doi.org/10.15294/jejak.v7i2.3894

EE. Siburian, O. (2012). Analisis Faktor-Faktor yang Mempengaruhi Ekspor Karet Alam Indonesia ke Singapura Tahun 1980-2010. Economics Development Analysis Journal, 1(2). https://doi.org/10.15294/edaj.v1i2.480

FF. Startienè, G., \& Remeikienè, R. (2014). Evaluation of Revealed Comparative Advantage of Lithuanian Industry in Global Markets. Procedia - Social and Behavioral Sciences, 110(2014), 428-438. https://doi.org/10.1016/j.sbspro.2013.12.887

GG. Suntharalingam, C., Ahmad, T. M. A. T., Ali, A. K., Rusli, R., \& Halim, N. A. (2011). Competitiveness of Malaysia's Fruits in the Global Agricultural and Selected Export Markets: Analyses of Revealed Comparative
Advantage (RCA) and Comparative Export Performance (CE). Economic and Technology Management Review, 6, 1-17.

HH. Syahputra, Y. R., Tarumun, S., \& Yusri, J. (2014). Analisis Daya Saing Ekspor Karet Alam (Natural Rubber) Indonesia di Pasar Internasional. Jurnal Online Mahasiswa Fakultas Pertanian Universitas Riau, 1(2), $1-9$.

II. The Ministry of Industry Republic of Indonesia. (2018). Making Indonesia 4.0. The Ministry of Industry Republic of Indonesia. https://www.kemenperin.go.id

JJ. The Ministry of Trade Republic of Indonesia. (2021). Perkembangan Ekspor Non Migas (Komoditi). Portal Statistik Perdagangan. http://statistik.kemendag.go.id/growth-of-non -oil-and-gas-export-commodity

KK. Tupamahu, Y. M. (2015). Analisis Daya Saing Ekspor Cengkeh Indonesia di Kawasan ASEAN dan Dunia. Jurnal Agribisnis Perikanan, $8(1), \quad 27$. https://doi.org/10.29239/j.agrikan.8.1.27-35

LL. UN Comtrade. (2021). UN Comtrade: International Trade Statistics. https://comtrade.un.org/data

MM. Virginia, A., \& Novianti, T. (2020). Non-Tariff Measures (NTMs) and Indonesian Natural Rubber Export to the Main Export Destination Countries. Journal of Developing Economies, 5(1), 57-69. https://doi.org/10.20473/jde.v5i1.18609

NN. Wardani, M. A., \& Mulatsih, S. (2017). Analisis Daya Saing dan Faktor-Faktor yang Memengaruhi Ekspor Ban Indonesia ke Kawasan Amerika Latin. Jurnal Ekonomi Dan Kebijakan Pembangunan, 6(1), 81-100. https://doi.org/10.29244/jekp.6.1.81-100

OO. World Bank. (2021). The World Bank Data. https://data.worldbank.org/indicator

PP. Zuhdi, F., \& Suharno. (2015). Analisis Daya Saing Ekspor Kopi Indonesia dan Vietnam di Pasar ASEAN 5. Jurnal Habitat, 26(3), $152-162$. https://doi.org/10.22437/jiseb.v20i1.5028 


\section{Appendix}

APPENDIX I

Automobile Domestic SALES in MidDle-East Countries (Units)

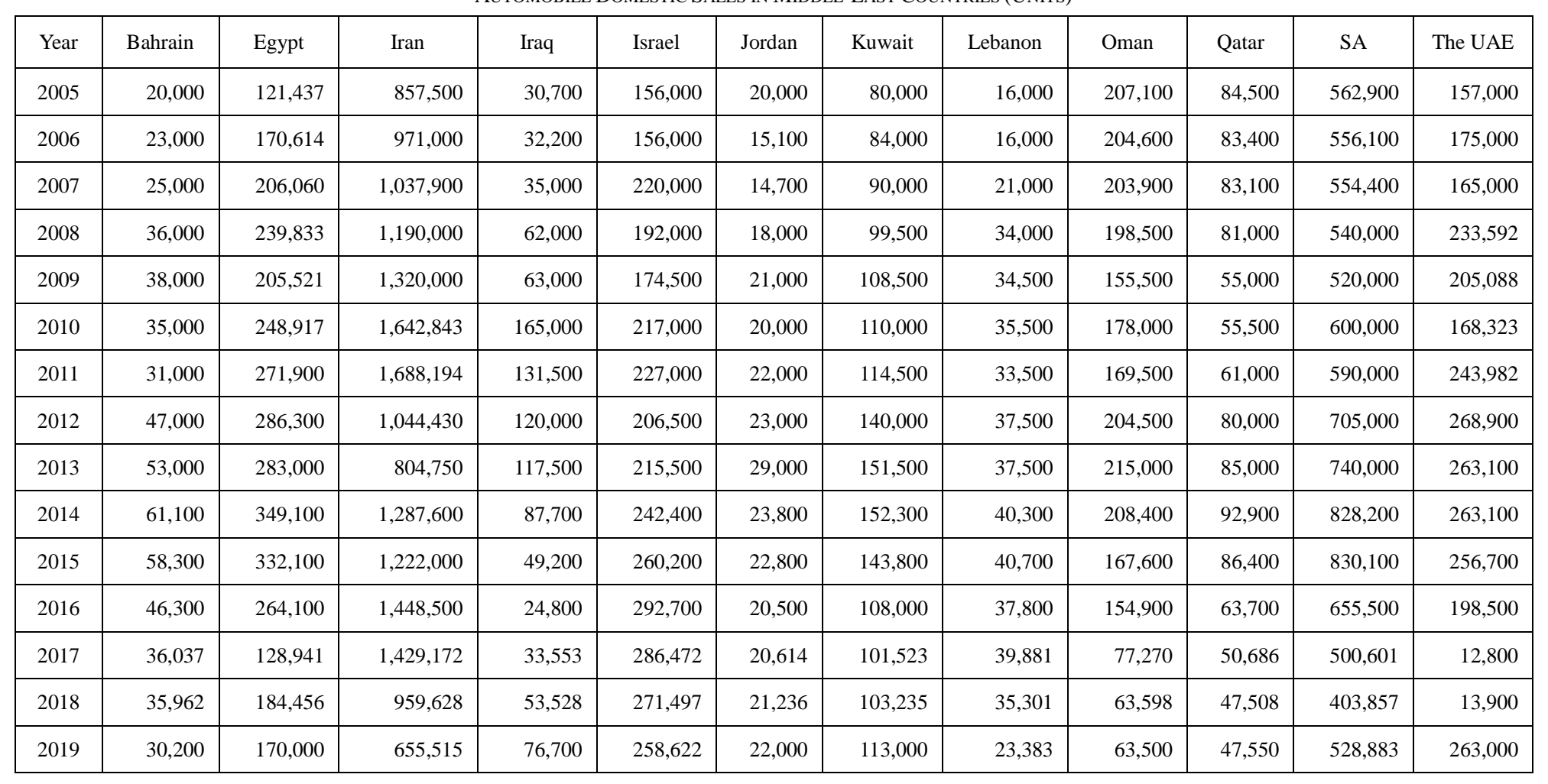

SOURCE: ORGANISATION INTERNATIONALE DES CONSTRUCTEURS D'AUTOMOBILES (OICA)

Note: THeRE ARE DATA LIMITATION FOR PALESTINE, Syria, AND YeMEN DUE TO DOMESTIC CONFLICT. HENCE, THEY ARE NOT INCLUDED ON THIS TABLE 
APPENDIX II

INDONESIAN AutOMOBILE EXPORT TO SELECTED MIDDLE-EAST COUNTRIES (US\$)

\begin{tabular}{|c|c|c|c|c|c|c|c|c|c|c|}
\hline Year & Bahrain & Egypt & Jordan & Kuwait & Lebanon & Oman & Qatar & SA & The UAE & Total \\
\hline 2006 & $1,261,802$ & $1,947,675$ & 168,163 & $4,838,019$ & $1,448,979$ & $3,914,647$ & $3,233,101$ & $75,490,864$ & $16,901,752$ & $109,205,002$ \\
\hline 2007 & $5,554,063$ & $9,508,143$ & 966,304 & $14,021,722$ & $10,634,517$ & $48,409,081$ & $9,463,771$ & $196,332,778$ & $111,038,175$ & $405,928,554$ \\
\hline 2008 & $8,365,469$ & $23,861,923$ & $1,511,769$ & $12,074,003$ & $17,151,538$ & $70,297,146$ & $7,183,681$ & $268,083,615$ & $110,525,496$ & $519,054,640$ \\
\hline 2009 & $2,711,516$ & $18,148,040$ & 421,365 & $9,400,497$ & $9,593,730$ & $16,279,850$ & $3,898,776$ & $115,852,518$ & $28,053,031$ & $204,359,323$ \\
\hline 2010 & $3,571,331$ & $7,057,156$ & 630,167 & $17,110,231$ & $6,920,086$ & $19,843,919$ & $5,217,485$ & $233,188,555$ & $47,354,421$ & $340,893,351$ \\
\hline 2011 & $4,425,803$ & $14,333,559$ & $1,097,830$ & $24,847,441$ & $4,628,147$ & $48,918,783$ & $9,673,889$ & $317,164,778$ & $84,770,959$ & $509,861,189$ \\
\hline 2012 & $7,191,020$ & $15,860,676$ & $2,226,056$ & $35,765,775$ & $13,668,509$ & $75,505,565$ & $16,564,690$ & $528,622,102$ & $120,956,718$ & $816,361,111$ \\
\hline 2013 & $13,272,942$ & $12,824,492$ & 798,753 & $48,092,541$ & $11,498,632$ & $63,051,854$ & $23,981,518$ & $528,628,659$ & $162,311,971$ & $864,461,362$ \\
\hline 2014 & $29,627,589$ & $11,082,702$ & $2,629,700$ & $58,657,417$ & $16,389,402$ & $91,065,445$ & $36,009,946$ & $684,153,171$ & $189,052,036$ & $1,118,667,408$ \\
\hline 2015 & $26,610,850$ & $7,912,633$ & $2,337,839$ & $58,763,981$ & $20,196,759$ & $44,576,555$ & $26,125,341$ & $873,466,698$ & $204,912,113$ & $1,264,902,769$ \\
\hline 2016 & $18,149,107$ & 951,499 & $1,691,301$ & $51,146,897$ & $12,348,668$ & $36,455,081$ & $14,077,474$ & $447,869,767$ & $69,710,168$ & $652,399,962$ \\
\hline 2017 & $23,566,857$ & 160,499 & $1,689,817$ & $31,359,420$ & $14,406,734$ & $92,110,052$ & $16,571,640$ & $494,133,463$ & $126,038,518$ & $800,037,000$ \\
\hline 2018 & $21,130,931$ & $11,173,435$ & $7,312,998$ & $41,815,074$ & $19,207,473$ & $149,681,253$ & $19,185,080$ & $373,446,050$ & $137,856,789$ & $780,809,083$ \\
\hline 2019 & $19,321,968$ & $17,878,645$ & $7,541,255$ & $63,426,299$ & $10,562,897$ & $140,778,926$ & $30,671,024$ & $455,034,707$ & $158,828,817$ & $904,044,538$ \\
\hline
\end{tabular}

SOURCE: UN COMTRADE (2021)

120 | Jurnal Akuntansi, Ekonomi dan Manajemen Bisnis | Vol. 9 No.2, December 2021, 111-121 | E-ISSN: 2548-9836 
APPENDIX III

RSCA INDICES OF INDONESIAN AUTOMOBILE IN SELECTED MidDLE-EAST COUNTRIES

\begin{tabular}{|c|c|c|c|c|c|c|c|c|c|}
\hline Year & Bahrain & Egypt & Jordan & Kuwait & Lebanon & Oman & Qatar & SA & The UAE \\
\hline 2006 & -0.10250 & -0.58307 & -0.96131 & -0.38011 & 0.05508 & -0.31110 & 0.56579 & 0.00933 & -0.53862 \\
\hline 2007 & 0.44935 & 0.04602 & -0.67894 & -0.05994 & 0.59488 & 0.50826 & -0.02224 & 0.40360 & 0.19014 \\
\hline 2008 & 0.38170 & 0.26781 & -0.82313 & -0.18150 & 0.50388 & 0.46998 & 0.05722 & 0.42543 & 0.03104 \\
\hline 2009 & 0.27830 & 0.15453 & -0.89888 & -0.12660 & 0.22618 & 0.12650 & 0.05214 & 0.15146 & -0.17679 \\
\hline 2010 & 0.20718 & -0.52046 & -0.83618 & 0.19911 & 0.19725 & 0.01431 & -0.01757 & 0.32123 & -0.09922 \\
\hline 2011 & 0.53526 & -0.29654 & -0.65483 & 0.30315 & 0.14231 & 0.32923 & 0.29621 & 0.43258 & 0.14840 \\
\hline 2012 & 0.42503 & -0.13279 & -0.38186 & 0.31442 & 0.55201 & 0.42061 & 0.24790 & 0.47597 & 0.21536 \\
\hline 2013 & 0.66408 & -0.24005 & -0.74330 & 0.42034 & 0.46740 & 0.45370 & 0.45680 & 0.51088 & 0.42188 \\
\hline 2014 & 0.75699 & -0.62521 & -0.42687 & 0.47214 & 0.61298 & 0.48265 & 0.63751 & 0.53764 & 0.24338 \\
\hline 2015 & 0.68193 & -0.74097 & -0.35222 & 0.49179 & 0.56915 & 0.38794 & 0.49504 & 0.61338 & 0.37856 \\
\hline 2016 & 0.67404 & -0.95746 & -0.54474 & 0.64036 & 0.41894 & 0.46782 & 0.54979 & 0.56682 & 0.00047 \\
\hline 2017 & 0.80118 & -0.98991 & -0.63439 & 0.50408 & 0.44147 & 0.54664 & 0.61224 & 0.66515 & 0.12036 \\
\hline 2018 & 0.80357 & -0.50514 & 0.11276 & 0.56893 & 0.52733 & 0.81463 & 0.65412 & 0.64548 & 0.19850 \\
\hline 2019 & 0.74711 & -0.29430 & 0.23114 & 0.54061 & 0.46378 & 0.64092 & 0.65879 & 0.59986 & 0.38243 \\
\hline Average & 0.52166 & -0.38697 & -0.54234 & 0.26477 & 0.41233 & 0.38229 & 0.37455 & 0.45420 & 0.10828 \\
\hline
\end{tabular}

SOURCE: AUTHOR's CALCULATION 